\title{
Bartosz Żukowski, Esse est percipi? Metafizyka idei George'a Berkeleya, Wydawnictwo Marek Derewiecki, Kęty 2012, ss. 206
}

DOI: http://dx.doi.org/10.12775/RF.2017.008

Jak połączyć jedną linią bez odrywania ręki dziewięć punktów ułożonych $\mathrm{w}$ postaci kwadratu? Wiemy dobrze, że rozwiązanie tej zagadki wymaga niekonwencjonalnego podejścia, podobnie jak w przypadku rozwiązania legendarnego węzła gordyjskiego przez Aleksandra Wielkiego. W obu sytuacjach wychodzimy poza ramy problemu i staramy się rozwiązać go niejako od zewnątrz. W przypadku schematu dziewięciu punktów łączenie linii odbywa się poza obrębem tworzonego przez punkty kwadratu. Węzeł gordyjski z kolei rozpada się w wyniku przecięcia go mieczem. Choć być może cenne w perspektywie osiągniętego celu, rozwiązania trudności w obu przypadkach nie obywają się bez konsekwencji: pierwotna struktura kwadratu zostaje naruszona, a długie dereniowe łyko tworzące węzeł zostaje przekształcone w wielość krótkich odcinków.

Podobny, pozornie nierozwiązywalny problem podejmuje polski badacz filozofii George’a Berkeleya i tłumacz jego Dzienników filozoficznych ${ }^{1}$ Bartosz Żukowski w książce pt. Esse est percipi? Metafizyka idei George'a Berkeleya, która ukazała się nakładem wydawnictwa Marek Derewiecki w Kętach w 2012 roku. Autor książki zwraca uwage czytelnika na wciąż aktualny w studiach nad filozofią Berkeleya konflikt między idealistycznymi i realistycznymi interpretacjami poglądów epistemologicznych i metafizycznych XVIII-wiecznego irlandzkiego filozofa. Żukowski sugeruje, że „[...] najważniejsze powstałe wokół niej [filozofii Berkeleya] kontrowersje mają źródło w bezkrytycznie przyjmowanym przez wszystkie wadzące się strony założeniu, że wygłaszając określone deklaracje, Berkeley nie mógł być gołosłowny"2. Nie godząc się na

1 Por.: G. Berkeley, Dzienniki filozoficzne, przeł. i oprac. B. Żukowski, Wydawnictwo słowo/obraz terytoria, Gdańsk 2007.

2 B. Żukowski, Esse est percipi? Metafizyka idei George'a Berkeleya, Wydawnictwo Marek Derewiecki, Kęty 2012, s. 7. 
ową sprzeczność stanowisk interpretacyjnych, proponuje jej rozwiązanie, które, jak przekonuje, wymaga innowacyjnego podejścia, podobnie jak starożytny węzeł gordyjski albo zagadka z dziewięcioma punktami. Trudności całemu problemowi dodaje bowiem przekonanie autora książki, że doktryna immaterializmu Berkeleya jest nieredukowalnie ambiwalentna i zawiera kontradyktoryczne twierdzenia, które odpowiadają za kontrowersje interpretacyjne.

Schematem, poza który prowadzi nas w swych rozważaniach autor książki Esse est percipi? jest historyczna metoda badań. Nie odmawia jej on wartości, ale nadaje funkcje propedeutyczną wobec analizy metafizycznej, która, jego zdaniem, ma prowadzić do odpowiedzi na pytanie o kluczową dla rozwikłania sporu interpretacyjnego teorię przedmiotu (idei) w Berkeleyowskim immaterializmie. Warto zwrócić uwagę, że na drodze rozwiązania sporu interpretacyjnego wokół poglądów Berkeleya innowacyjne jest zarówno postawione pytanie, jak i zaproponowana metafizyczna metoda badań, której charakter z natury pozostaje abstrakcyjny. Skłania ona także do posłużenia się nowymi kategoriami, spoza filozofii Berkeleya, co autor książki czyni z zamiarem i pełną odpowiedzialnością, podając szczegółowe definicje nowo wprowadzonych terminów. Inspiracją dla niego sa, jak wskazuje, praca Étienne'a Gilsona pt. Byt $i$ istota ${ }^{3}$ czy badania Charlesa Kahna zaprezentowane w zbiorze Język i ontologia ${ }^{4}$. We Wstępie Żukowski stwierdza, że dzięki takiemu podejściu będzie możliwe odsłonięcie "głębokiej ambiwalencji tkwiącej w sercu Berkeleyowskiego systemu" ${ }^{\prime \prime}$, która polega na przyjęciu przez irlandzkiego filozofa tezy o istnieniu rzeczy jedynie w umyśle oraz równoczesnym uznaniu ich pełnej realności. Zdaniem autora książki bowiem "Spór o Berkeleya będzie więc trwał w istocie tak długo, jak długo nierozwiązana pozostanie czysto teoretyczna kwestia, czy w ogóle możliwe jest, aby w warunkach Berkeleyowskiego immaterializmu przedmiot poznania zachował przedmiotową odrębność i realność"6.

Na czym w istocie polega innowacyjne rozwiązanie problemu sporu o właściwą interpretację poglądów Berkeleya, jakie proponuje Bartosz Żukowski? Przede wszystkim zwraca on uwagę, na to, że filozofia brytyjskiego filozofa nie jest prostym i konsekwentnym systemem, a dodatkowo obarczona jest problemem błędnego koła. Pisze, że „Ugruntowanie immaterializmu uderza $\mathrm{w}$ realizm, ocalenie realizmu podkopuje zaś fun-

3 É. Gilson, Byt i istota, przeł. D. Eska, J. Nowak, Instytut Wydawniczy PAX, Warszawa 2006.

${ }^{4}$ Ch. Kahn, Język i ontologia, przeł. B. Żukowski, Wydawnictwo Antyk, Kęty 2008.

5 B. Żukowski, op. cit., s. 7.

6 Ibidem, s. 21. 
damenty immaterializmu - oto błędne koło, w które nieuchronnie wikła się Berkeleyowski immaterializm"7. Zdaniem autora monografii zarówno interpretacje idealistyczne, jak i realistyczne są uprawnione w odniesieniu do filozofii Berkeleya, dostarcza ona bowiem ku temu przesłanek. Pozostają one uprawnione jedynie wtedy, kiedy nie pretendują do przekonania o całościowym ujęciu koncepcji irlandzkiego filozofa8.

Tak w przypadku rozwiązania węzła gordyjskiego, jak i zagadki z dziewięcioma punktami nie należy ulegać fałszywemu złudzeniu, że choć być może proste, to zaproponowane rozwiązanie jest możliwe do osiągnięcia szybko i w łatwy sposób. Rozwiązanie problemu sporu o interpretację poglądów Berkeleya wymagało od autora monografii przeprowadzenia szczegółowych rozważań w postaci analizy abstrakcyjnej na 206 stronach. Jedynym rozdziałem dostarczającym bardziej konkretnych ilustracji abstrakcyjnych rozważań dotyczących metafizycznej struktury idei w filozofii Berkeleya jest rozdział VII. Dodatkowym argumentem na rzecz stopnia trudności problemu, jaki warto w tym miejscu podkreślić jest fakt, że w założeniu autora książki przeprowadzona analiza dotyczy jedynie dwóch dzieł Berkeleya: Dzienników filozoficznych oraz pierwszego wydania Traktatu o zasadach poznania ludzkiego.

Monografia składa się z dwóch zasadniczych części. Pierwsza została poświęcona omówieniu metafizycznych uwarunkowań immaterializmu Berkeleya. W odpowiedzi na zasadnicze pytanie o to, "Jakie generalne metafizyczne założenia dotyczące bytowej warstwy przedmiotu musi przyjąć doktryna, która z materializmem zamierza rozprawić się przy pomocy teorii egzystencjalnej?"' , autor książki podejmuje w trzech kolejnych rozdziałach zagadnienia dotyczące kategorii istnienia, mierząc się z problemami pluralizmu egzystencjalnego, przedmiotowej konstytutywności sposobu istnienia idei oraz monoegzystencjalizmu. Odwołując się do istotnych założeń w rozważaniach Berkeleya, Żukowski dowodzi, po pierwsze, że teza esse est percipi wymaga odrzucenia abstrakcyjnej kategorii istnienia i przyjęcia, że za każdym zastosowaniem przez Berkeleya terminu „istnienie” kryje się konkretnie nacechowany sposób egzystowania. Po drugie, przyjmując doktrynę przedmiotowej relatywizacji istnienia, przekonuje, że sposób istnienia obiektu jest ściśle powiązany z jego naturą. Autor podkreśla kilkukrotnie, że idea Berkeleya składa się ze ściśle $\mathrm{z}$ sobą powiązanych elementów bycia postrzeganą oraz z nacechowania jakościowego (zasada elementarności idei). Gdyby natura idei miała być różna od wskazanych elementów, musiałaby być niepostrzegalna - to jest musiałaby istnieć w pozazmysłowym świecie,

7 Ibidem, s. 101-102.

8 Por. ibidem, s. 101-103.

9 Ibidem, s. 21. 
co pozostawałoby w sprzeczności z założeniami filozofii Berkeleya ${ }^{10}$. Po trzecie, autor monografii odrzuca możliwość więcej niż jednego sposobu istnienia idei, rozumianego jako istnienia niepercepcyjne, podkreślając przy tym, że przyjęcie możliwości istnienia idei na wiele sposobów spowodowałoby, że sposób istnienia przestałby mieć konstytutywny charakter dla idei, co wcześniej zostało wykazane jako słuszne ${ }^{11}$.

W drugiej części książki została przedstawiona immaterialistyczna teoria przedmiotu wraz ze szczególnym uwzględnieniem kwestii dotyczących strukturalnej zależności idei od umysłu ludzkiego na gruncie Berkeleyowskiego immaterializmu. Zostały one omówione w osobnych rozdziałach poświęconych kolejno: zagadnieniu jakościowej i egzystencjalnej suwerenności idei, elementarności i jednolitości idei, inspirowanej Kahnowską koncepcją czasownika 'być', analizie lingwistycznej doktryny esse est percipi oraz problemowi metafizycznej struktury idei i solipsyzmu.

Ważnym problemem podniesionym $\mathrm{w}$ drugiej części książki jest kwestia definicji kategorii realności idei. Żukowski wskazuje, że na gruncie filozofii Berkeleya należy rozumieć ją w odwołaniu do zależności przyczynowej wobec umysłu. Realność to niezależność, transcendencja idei wobec umysłu. Jej przeciwieństwem z kolei jest „,...] kauzalna immanencja zasadzająca się na przyczynowej zależności od poznającego umysłu"12. Wyróżniając dwa możliwe rodzaje wspomnianej suwerenności idei: jakościową lub inaczej przedmiotową (w rozumieniu suwerennego nacechowania jakościowego) i egzystencjalną, tj. posiadanie niezależnego, nieuzyskiwanego od innych obiektów sposobu istnienia, autor książki starał się wykazać, że na gruncie filozofii Berkeleya idee nie mogą posiadać drugiej z wymienionych. Prowadzi to jednak do paradoksu. Jak zauważa autor, „[...] obdarzenie obiektu przedmiotową suwerennością $[. .$.$] całkowicie niweluje wszelką przewagę immateriali-$ zmu w zakresie pewności i adekwatności poznania. [...] Jeden z najbardziej ironicznych paradoksów polega jednak na tym, że tylko nadanie idei przedmiotowej suwerenności, tylko ontologiczne wyemancypowanie spod władzy podmiotu pozwala ocalić jej realność"13. W rozdziałach V-VIII autor wskazuje, że budowa idei u Berkeleya jest oparta na modelu komponentowym, w którym oba elementy idei są ze sobą ściśle powiązane i zasadniczo nieodróżnialne. Analizując tezę esse est percipi, zaznacza, że idea Berkeleya nie może być ani egzystencjalnie, ani strukturalnie niezależna względem aktu postrzegania, stąd opis relacyjno-operacyjny,

\footnotetext{
10 Por. ibidem, s. 47-67.

11 Por. ibidem, s. 58-68.

Ibidem, s. 73.

13 Ibidem, s. 97.
} 
jaki nasuwa się wobec podstawowej tezy systemu Berkeleya musi zostać uzupełniony o opis definicyjny. Bycie idea polega bowiem na byciu postrzeganą. Jest to jeden ze sposobów rozumienia, czym jest idea na gruncie filozofii Berkeleya. W odniesieniu do rozważań z Traktatu oraz wybranych notatek z Dzienników autor monografii pokazuje, że idea nie była utożsamiana $\mathrm{z}$ postrzeżeniem, ale $\mathrm{z}$ przedmiotem postrzegania. Jako twór Boga - stanowiącego przyczynę realnych idei, była ona wrażana w ludzki umysł jako gotowy przedmiot. Żukowski stwierdza jednak, że owa „Intencjonalna koncepcja percepcji i związana z nią koncepcja idei jako obiektu przedmiotowo suwerennego jest nie do utrzymania na gruncie Berkeleyowskiego immaterializmu"14.

Ostatnim problemem, który zostaje poddany w monografii szczegółowym badaniom jest kwestia intersubiektywności idei. Jednym z rozwiązań jest możliwość wskazania na istnienie wspólnego korelatu umysłowego, który występuje we wszystkich aktach percepcyjnych. Jako taki miałby być on umiejscowiony w umyśle Boga, co jak pokazuje Żukowski, rodzi problemy z pogodzeniem owej teorii z immaterializmem Berkeleya. Korelat taki nie mógłby, jego zdaniem, być rozumiany ani jako atrybut Boga, własność, komponent lub moment jego umysłu, ani jako boskie postrzeżenie. W pierwszym przypadku musielibyśmy przyznać, że bycie postrzeganym nie należy do komponentów konstytutywnych przedmiotu poznania, w drugim - musielibyśmy utożsamić postrzeżenia ludzkie $\mathrm{z}$ boskimi. $\mathrm{W}$ drugiej propozycji rozwiązania problemu intersubiektywności zamiast jednego korelatu Żukowski wskazuje na wielość identycznych przedmiotów jedynie różnych od siebie numerycznie, którą Berkeley miał sugerować w Trzech Dialogach miedzy Hylasem i Filonousem. Nie pozostawała ona jednak wolna od trudności. W związku $\mathrm{z}$ tym, że operacja postrzegania konstytuowała sposób istnienia $\mathrm{w}$ teorii Berkeleya, między ideą a umysłem zachodziła nierozerwalna więź strukturalna wykluczająca przedmiotową odrębność. Pozorność różnicy między ideami przekładałaby się automatycznie na pozorną różnicę między umysłami. Ponadto niemożliwe jest samo założenie doskonałego podobieństwa czy nieodróżnialności przedmiotów, co trudne jest do stwierdzenia, kiedy podmioty postrzegające różni z konieczności perspektywa prowadzonej obserwacji. Unaocznia to zatem pułapkę solipsyzmu, w jaką uwikłany jest system Berkeleyowskiego immaterializmu egzystencjalnego ugruntowanego na ścisłym związku między różnicą jakościową i przedmiotową. Jak czytamy w podsumowaniu rozdziału VIII: „Zachowanie jedności świata doświadczenia może się dokonać na gruncie tego systemu jedynie za cenę przyjęcia jedności poznającego umysłu, co wyklucza intersubiektywność i implikuje solipsyzm [...]. Za-

14 Ibidem, s. 180. 
chowanie odrębności poznających umysłów wymaga zaś umieszczenia ich w różnych światach doświadczenia, co również oznacza solipsyzm. W ostatecznym rozrachunku Berkeleyowski immaterializm skazany jest więc na wybór między solipsyzmem mono- i multipsychistycznym"15.

Bez wątpienia można powiedzieć, że lektura monografii pt. Esse est percipi? Metafizyka idei George'a Berkeleya jest wymagająca. Obszar problemowy z filozofii George Berkeleya, do którego sięga Bartosz Żukowski, jest złożony. Stopień jego zawiłości i trudności doskonale obrazuje odwołanie do fragmentu utworu Żadne z nich Samuela Becketta, który kończy książkę. Drobiazgowe analizy abstrakcyjne prowadzone z pomocą nowoczesnych kategorii ontologicznych wymagają zatem niewątpliwie skupienia. W śledzeniu ich związków z rozważaniami Berkeleya czytelnikowi może brakować odwołania do poszczególnych fragmentów $\mathrm{z}$ dzieł filozofa in extenso. Mimo to stawka w postaci uzyskania propozycji zażegnania trwającego od lat sporu interpretacyjnego o właściwą interpretację Berkeleya wydaje się warta podjęcia wysiłku. Tym bardziej, że autor monografii wynagradza go czytelnikowi w dwójnasób. Po pierwsze, prowadząc wywód w sposób nie tylko logiczny, ale i żywiołowy, przekazuje on pasję wobec Berkeleyowskich rozważań nad naturą bytu i poznania, które nadal stanowią istotny element $\mathrm{w}$ światowych badaniach nad myślą brytyjskiego filozofa ${ }^{16}$. Po drugie inspiruje do przypomnienia sobie lub zapoznania się z tradycją polskich studiów nad realizmem lub idealizmem Berkeleya, jakie podejmowali m.in. Kazimierz Ajdukiewicz, Henryk Elzenberg czy Roman Ingarden, których znajomość w kontekście wspomnianych badań światowych jest bezwzględnie istotna.

Nie zamierzam rozstrzygać $\mathrm{w}$ tym miejscu, czy rozwiązanie problemu sporu wokół interpretacji poglądów Berkeleya, jakie poprzez odwołanie się do abstrakcyjnych rozważań nad strukturą metafizyczną Berkeleyowskiej idei zaproponował Bartosz Żukowski, jest zasadne. Z pewnością wyjście poza obszar pojęciowy właściwy dla Berkeleya oraz zastosowanie analiz lingwistycznych zainspirowanej przez badania Charlesa Kahna jest w tym względzie oryginalne i innowacyjne. Tak jak połączenie dziewięciu punktów czterema liniami bez odrywania ręki, z koniecznością wyjścia poza ramy kwadratu wyznaczonego przez punkty, czy przecięcie węzła gordyjskiego na wielość mniejszych odcinków, propozycja autora monografii usuwa, jak się wydaje, wspomnianą trudność. Zachęcam jednak każdego czytelnika do samodzielnej lektury

15 Ibidem, s. 196.

16 Por. S. H. Daniel, How Berkeley's Works are Interpreted?, w: George Berkeley: Religion and Science in the Age of Enlightenment, ed. S. Parigi, Springer, Dordrecht 2010, s. $3-15$. 
książki i prześledzenia toku argumentacji Bartosza Żukowskiego oraz do tego, aby sam ocenil, czy i w jakim stopniu owo rozwiązanie chce przyjąć.

Marta Szymańska-Lewoszewska Uniwersytet Mikołaja Kopernika, Toruń e-mail: martaewa.szymanska@gmail.com 